\title{
RESIDU PESTISIDA ALDRIN DAN DIELDRIN PADA SAMPEL TANAH DAN AIR DI DESA SRIGADING KECAMATAN SANDEN KABUPATEN BANTUL
}

\section{ALDRIN AND DIELDRIN PESTICIDE RESIDUE IN SOIL AND WATER SAMPLE FROM SRIGADING VILLAGE SANDEN DISTRICT BANTUL REGENCY}

\author{
Iin Narwanti', Eko Sugiharto ${ }^{2}$, Chairil Anwar ${ }^{2}$ \\ ${ }^{1}$ Fakultas Farmasi Universitas Ahmad Dahlan \\ Jln. Prof. Dr. Supomo Yogyakarta, Telp. (0274) 379418 \\ Email : iin.narw@gmail.com
}

\begin{abstract}
Abstrak
Telah dilakukan penelitian terhadap residu pestisida aldrin dan dieldrin pada sampel tanah dan air di Desa Srigading, Kecamatan Sanden, Kabupaten Bantul. Penelitian ini bertujuan untuk menganalisis, mengidentifikasi dan mengevaluasi residu pestisida aldrin dan dieldrin pada tanah dan air. Sampel berasal dari lahan pertanian di Desa Srigading. Sampel tanah diekstraksi menggunakan shaker dengan pelarut aseton, sampel air diekstraksi menggunakan corong pisah dengan pelarut campuran $15 \%$ (v/v) diklorometana/n-heksana. Clean-up dilakukan dengan kolom kromatografi menggunakan florisil dan selanjutnya kadar residu pestisida ditentukan dengan kromatografi gas yang dilengkapi dengan detektor tangkapan elektron (Electron Capture Detector/ECD). Hasil penelitian menunjukkan bahwa sampel tanah dan air terdeteksi adanya residu pestisida aldrin dan dieldrin. Kisaran residu pestisida pada sampel tanah untuk aldrin (4,8-64,8 ppb) dan dieldrin (tidak terdeteksi-6,0 ppb), sedangkan pada sampel air untuk aldrin (tidak terdeteksi-1,0 ppb) dan dieldrin (tidak terdeteksi-1,2 ppb).Residu pestisida pada sampel sampel air di lahan pertanian Desa Srigading masih berada di bawah baku mutu air yang telah ditetapkan.
\end{abstract}

Kata kunci : residu pestisida, aldrin, dieldrin

\footnotetext{
${ }^{2}$ Fakultas MIPA Universitas Gadjah Mada
} 


\begin{abstract}
Aldrin and dieldrin pesticide residue in soil and water samples from Srigading Village, Sanden District, Bantul Regency has been investigated. The purpose of this study were to analyze, identificate and evaluate pyrethroid pesticide residues in soil and water samples. Soil sample was extracted using shaker with acetone solvent. Water samples was extracted using separator funnel with $15 \%(\mathrm{v} / \mathrm{v})$ dichloromethane/n-hexane solvent.Clean-up was couducted using chromatography column using florisil and determination of pesticide residue in the samples was carried out by gas chromatography apparatus equipped with electron capture detector (GC-ECD). The result showed that pesticide residues in soil sample in the range level: aldrin $(4,8-64,8 \mathrm{ppb})$ and dieldrin (not detected-6,0 ppb). In water sample pesticide residues in the range level: aldrin (not detected-1,0 ppb) dan dieldrin (-not detected1,2 ppb). The quality or water sample taken from onion field is laid under the standard of water that has been settled.
\end{abstract}

Keywords : pesticide residue, aldrin, dieldrin

\section{PENDAHULUAN}

Keberhasilan pembangunan industri dan pertanian di Indonesia mengalami perkembangan di mana di sektor pertanian ditunjukkan pada produksi pangan dan holtikultura/ sayuran. Terjadi peningkatan dari tahun ke tahun seiring dengan kemajuan pembangunan yang telah dilaksanakan. Usaha yang dilakukan untuk meningkatkan produksi pertanian/ sayuran antara lain dengan ekstensifikasi, diversifikasi, rehabilitasi, dan intensifikasi pertanian. Intensifikasi merupakan usaha yang cukup dominan sumbangannya dalam produksi sayuran. Usaha tersebut dikembangkan antara lain dengan penggunaan varietas unggul dan bahan-bahan agrokimia seperti pupuk dan pestisida.

Pada mulanya pestisida organoklor diandalkan sebagai agen pengendali organisme penganggu tanaman. Organoklor merupakan pestisida yang berpotensi menyebabkan kerusakan lingkungan dan mengancam kesehatan manusia. Dampak negatif yang muncul akibat penggunaan senyawa ini lebih tinggi bila dibandingkan dengan senyawa lain, karena senyawa ini peka terhadap sinar matahari dan tidak mudah terurai (Sa`id, 1994). Organoklor mempunyai toksisitas tinggi dan bersifat persisten oleh karena itu penggunaannya dilarang oleh pemerintah. Persistensi organoklor yang tinggi menyebabkan senyawa organoklor dapat terakumulasi di lingkungan selama bertahun-tahun.

Senyawa organoklor mempunyai rumus umum $\mathrm{C}_{\mathrm{x}} \mathrm{H}_{\mathrm{y}} \mathrm{Cl}_{\mathrm{z}}$. Berdasarkan struktur molekulnya, organoklor dibagi menjadi tiga yaitu turunan benzena, siklodiena dan DDT. Contoh pestisida organoklor turunan benzena adalah HCB (heksaklorobenzena) dan $\mathrm{HCH}$ (heksaklorosikloheksana). HCB diproduksi melalui klorinasi benzena dengan bantuan katalis, sedangkan $\mathrm{HCH}$ diproduksi melalui klorinasi benzena dengan radiasi UV. Pestisida organoklor siklodiena yang meliputi endrin, heptaklor, aldrin dan dieldrin, merupakan senyawa siklis yang mempunyai karakteristik jembatan endometilen. DDT diproduksi melalui reaksi kondensasi kloral dengan klorobenzena di bawah kondisi asam. Senyawa organoklor bersifat racun kontak dan racun perut yang efektif mengendalikan larva, nimfa dan imago. Selain itu, organoklor mempunyai toksisitas yang sedang terhadap mamalia dan persistensinya yang lama di lingkungan, baik di tanah, jaringan tanaman maupun hewan.

Senyawa organoklor bersifat neurotoksik dan efek akutnya adalah serangan terhadap sistem syaraf pusat, melalui hambatan pada kerja asam $\gamma$-aminobutirat yang menginduksi influks ion klorida ke sistem syaraf pusat (Ert dan Sullivan, 1982). Senyawa organoklor juga berpengaruh terhadap hormon endokrin sehingga digolongkan sebagai Endocrine Disruption Compound (EDC).

Aktivitas pestisida berspektrum luas, oleh karena itu aplikasi pestisida dapat menimbulkan permasalahan serius bagi ekosistem diantaranya terjadinya resistensi, ledakan hama sekunder dan resurjensi hama. Beberapa jenis serangga yang dalam keadaan normal bukan merupakan hama dapat berubah statusnya menjadi hama setelah penggunaan pestisida. Resistensi hama terjadi karena terbunuhnya musuh alami oleh pestisida yang digunakan. Laba dkk. (2000) melaporkan bahwa penggunaan pestisida organofosfat dapat menimbulkan resurjensi hama wereng batang coklat. Aplikasi pestisida juga berpengaruh terhadap lebah dan serangga penyerbuk lainnya, hal ini dikarenakan organisme tersebut bersifat sangat peka terhadap berbagai jenis pestisida.

Di lingkungan perairan, pestisida juga berpengaruh buruk terhadap populasi beberapa jenis 
organisme seperti ikan dan udang. Terhadap organisme perairan, pestisida organoklor toksik terhadap berbagai jenis spesies ikan, di mana dieldrin dan aldrin menunjukkan toksisitas paling tinggi terhadap organisme perairan. Residu pestisida di lingkungan merupakan akibat dari penggunaan atau aplikasi pestisida tertentu yang ditujukan pada sasaran tertentu seperti pada tanaman dan tanah. Akan tetapi dapat juga sebagai akibat pestisida yang terbawa (drift) oleh gerakan air seperti sungai, air, tanah dan oleh gerakan angin/udara. Residu pestisida adalah zat kimia yang terkandung dalam hasil pertanian, bahan pangan atau pakan hewan baik sebagai akibat langsung maupun tak langsung dari penggunaan pestisida (Komisi Pestisida, 1997).

Penelitian terhadap residu pestisida pada tanah tadah hujan maupun sawah irigasi telah dilakukan oleh Ardiwinata, dkk. (1999). Dari penelitian tersebut dilaporkan bahwa pada lahan pertanian sering ditemukan adanya residu insektisida $\mathrm{BHC}$ dan aldrin, baik pada tanah, beras maupun air. Hal ini terkait dengan adanya penggunaan pestisida pada masa lampau dan sifatnya yang persisten. Residu insektisida ini tidak hanya terdifusi ke dalam tanaman, tetapi juga lingkungan sekitarnya, yang pada akhirnya dapat mengkontaminasi rantai makanan.

Adanya aplikasi pestisida aldrin dan dieldrin oleh petani di masa yang lampau dan berdasarkan sifat bioakumulasi dan persistensi aldrin dan dieldrin yang tinggi, diduga dalam sampel tanah dan air terdapat residu pestisida aldrin dan dieldrin, oleh karena itu dalam penelitian ini dilakukan penetapan kadar residu pestisida aldrin dan dieldrin pada sampel tanah dan air.

\section{METODE PENELITIAN}

\section{Bahan}

Bahan yang digunakan dalam penelitian ini, meliputi: aseton (E. Merck), n-heksana (E. Merck), $\mathrm{Na} \mathrm{SO}$ anhidrat (E. Merck), florisil, karbon aktif, celite 545-magnesium, kertas saring, akuades, larutan standar pestisida organoklor (aldrin dan dieldrin), sampel tanah dan air.

\section{Alat}

Alat yang digunakan dalam penelitian ini, meliputi: penggojog mekanik (shaker), kolom florisil, alat-alat gelas, rotary evaporator, alat homogenizer, pompa vakum, penyaring Buchner, penangas air, timbangan analitik, satu set kromatografi gas (GC-2014 Shimadzu) yang dilengkapi dengan ECD dan kolom Rtx-1 (panjang kolom $30 \mathrm{~m}$, diameter dalam $0,25 \mathrm{~mm})$.

\section{Jalannya Penelitian}

\section{Pengambilan sampel}

Sampel tanah dan air diambil dari lahan pertanian di Desa Srigading, Kabupaten Bantul. Pada lahan ditentukan tempat titik pengambilan sampel tanah individu dengan cara: sistematik, seperti sistem diagonal atau zig-zag atau acak. Permukaan tanah dibersihkan dari rumput, kerikil dan sisa-sisa tanaman. Tanah diambil sampai kedalaman lapisan olah dengan menggunakan bor tanah, dimana setiap titik pengambilan dibor sedalam $20 \mathrm{~cm}$. Pengambilan sampel dilakukan secara komposit. Sampel komposit yang merupakan gabungan sampel individu (4-5 sampel), selanjutnya diambil kira-kira $1 \mathrm{~kg}$ dan dimasukkan ke dalam kantong plastik. Sampel komposit diberi label yang berisi keterangan: kode, tanggal pengambilan, dan lokasi (desa, kecamatan, dan kabupaten). Sampel tanah dikeringkan, kemudian dianalisis sifat fisiko-kimia tanah dan kadar residu pestisida. Sampel air komposit yaitu sampel air campuran dari 4-5 sampel air individu. Sampel air yang diambil adalah air bawah permukaaan dengan kedalaman 0-100 cm. Sampel tersebut dicampur, selanjutnya diambil sebanyak 500-1000 mL dimasukkan ke dalam wadah dan diberi label yang memuat keterangan: kode, tanggal pengambilan, dan lokasi (desa, kecamatan, dan kabupaten).

\section{Preparasi Sampel Tanah}

Sampel tanah yang telah dikeringkan (dengan cara diangin-anginkan) ditimbang sebanyak 25 gram, kemudian dimasukkan ke dalam labu alas bulat dan ditambahkan pelarut aseton sebanyak $100 \mathrm{~mL}$ dan selanjutnya ditutup. Labu alas bulat yang berisi sampel tersebut digojok dengan alat shaker selama 20 menit dengan kecepatan secukupnya. Setelah 20 menit, ekstraksi diulangi dengan memutar kembali waktu dan kecepatan yang sama, kemudian corong pisah diletakkan pada statif dan dibiarkan sampai terjadi pemisahan antara pelarut dengan sampel, selanjutnya didekantir.

Filtrat dievaporasi dengan evaporator, kemudian diekstraksi dengan n-heksana $25 \mathrm{~mL}$ sebanyak 2 kali, selanjutnya dilakukan clean-up dengan melewatkan sampel pada kolom kromatografi yang telah diisi florisil dan natrium sulfat anhidrat. Eluat dievaporasi hingga $\pm 1 \mathrm{~mL}$ kemudian labu dibilas dengan aseton secara bertahap dan hasil bilasannya ditampung dalam tabung uji hingga volume $10 \mathrm{~mL}$ dan larutan sampel siap disuntikkan ke kromatografi gas. 


\section{Preparasi Sampel Air}

Sebanyak $100 \mathrm{~mL}$ sampel air dimasukkan ke dalam corong pisah kemudian tambahkan $50 \mathrm{~mL}$ campuan $15 \%(\mathrm{v} / \mathrm{v})$ diklorometana/n-heksana (DH) an diekstraksi selama 2 menit. Selanjutnya didiamkan sehingga terbentuk dua lapisan, yaitu aqueous di lapisan bawah dan DH di lapisan atas. Lapisan bawah ditampung pada erlenmeyer, sedangkan lapisan atas (DH) pada labu bulat. Lapisan bawah dimasukkan lagi ke dalam corong pisah dan diekstrak lagi seperti semula sampai tiga kali.

Lapisan atas hasil ekstraksi diclean-up dengan melewatkannya pada kolom kromatografi yang telah diisi florisil dan sodium sulfat anhidrat, kemudian labu bulatnya dicuci dengan $n$-heksana sebanyak 10 $\mathrm{mL}$ kemudian dimasukkan lagi ke kolom kromatografi dan ulangi pencucian sampai tiga kali, setelah selesai larutan sampel dievaporasi sampai \pm 1 $\mathrm{mL}$ kemudian labu dibilas dengan aseton secara bertahap dan hasil bilasannya ditampung dalam tabung uji hingga volume $10 \mathrm{~mL}$ dan larutan sampel siap disuntikan ke kromatografi gas.

\section{Pembuatan Kurva Standar}

Kurva standar dibuat dengan membuat serial larutan standar pestisida. Sebanyak $1 \mu \mathrm{L}$ larutan standar diinjeksikan pada alat kromatografi gas sehingga diperoleh hubungan konsentrasi dengan luas area larutan standar.

\section{Penetapan Kadar Residu Pestisida}

Kondisi kromatografi gas untuk analisis residu pestisida adalah: tipe kromagtografi gas: GC-2014 Shimadzu; suhu injektor: 230 C; suhu kolom: 270 C; jenis kolom: Rtx-1 (panjang kolom $30 \mathrm{~m}$, diameter dalam 0,25 mm); fasa gerak: gas $\mathrm{N}$, laju $22 \mathrm{~mL} / \mathrm{menit}$, tekanan $65 \mathrm{kPa}$ ); fasa diam: crossbond $100 \%$ dimetil polisiloksan: detektor ECD. Selanjutnya dilakukan penyuntikan sebanyak $1 \mu \mathrm{L}$ larutan sampel siap suntik dan larutan standar pestisida ke kromatografi gas hingga diperoleh luas puncak dan waktu retensi.

\section{HASIL DAN PEMBAHASAN}

\section{Analisis Residu Pestisida Aldrin dan Dieldrin Dengan Kromatografi Gas}

Pada penelitian ini, residu pestisida aldrin dan dieldrin dianalisis dengan menggunakan alat kromatografi gas. Preparasi sampel dengan proses ekstraksi, clean-up dan penentuan residu pestisida.

Ekstraksi dilakukan dengan alat homogenizer dipilih karena efisiensinya yang lebih baik dibandingkan dengan metode yang lain. Tujuan ekstraksi ini, untuk memisahkan secara kuantitatif analit dari matriks pembawanya (ko-ekstraktan). Dengan adanya ko-ekstraktan ini dapat berpengaruh pada efisiensi ekstraksi dan clean up.

Untuk analisis residu pestisida, florisil merupakan adsorben yang biasa digunakan sebagai kolom clean-up. Florisil merupakan senyawa magnesium silikat, $\mathrm{Mg} \mathrm{SiO}_{3}$, yang dihasilkan dari presipitasi natrium silikât dengan magnesium sulfat. Proses clean-up dengan kolom florisil ini, ko-ekstraktan yang terdapat pada sampel komoditas pertanian seperti lemak, fosfolipid, pigmen, lilin dan pengotor lainnya dapat dihilangkan. Lee dkk. (1982) melaporkan bahwa florisil ini sangat baik digunakan untuk sampel yang berlemak maupun tak berlemak dan juga memperlihatkan nilai perolehan kembali relatif lebih tinggi bila dibandingkan dengan adsorben lainnya. Menurut Ishii (2003), proses clean-up dengan kolom florisil ini dilakukan untuk memfasilitasi penentuan residu insektisida dengan GC-ECD atau HPLC. Kondisi sistem kromatografi gas dalam penelitian ini sebagai berikut; temperatur injektor, $250^{\circ} \mathrm{C}$; splitless injection pada volume $1 \mu \mathrm{L}$ dengan auto injector; laju alir gas $\mathrm{N}_{2}, 22 \mathrm{~mL} /$ menit; kolom kapiler; Rtx-1 (30 m x 0,25 mm x 0,25 $\mu \mathrm{m})$ dengan fasa diam crossbond $100 \%$ dimetilpolisiloksan; temperatur kolom, $230^{\circ} \mathrm{C}$; ECD; temperatur detektor: $250^{\circ} \mathrm{C}$.

Tanah merupakan bagian dari litosfer yang berfungsi sebagai reservoir utama senyawa kimia yang masuk ke lingkungan. Tanah tersusun atas fraksi mineral dan organik. Fraksi mineral tersusun atas partikel pasir, debu, mineral lempung serta mineral lainnya, sedangkan fraksi organik terbentuk dari proses dekomposisi organisme.

Peningkatan persistensi pestisida seperti organoklor terjadi pada tanah dengan kandungan materi organik dan lempung yang tinggi serta aktivitas mikrobial yang rendah. Connel dan Miller (1995) melaporkan bahwa keberadaan residu pestisida di dalam tanah sangat erat kaitannya dengan kandungan bahan organik tanah. Semakin tinggi kandungan bahan organik tanah, semakin kuat menahan residu pestisida. Pestisida cenderung menumpuk pada lapisan tanah dengan kedalaman 10-20 cm karena pada lapisan tersebut banyak terkandung bahan organik sehingga pestisida mudah teradsorpsi dan sukar untuk hilang.

Dengan alat kromatografi gas diperoleh hasil berupa kromatogram yang akan digunakan untuk konfirmasi identitas senyawa yang dianalisis. Waktu retensi adalah waktu yang diperlukan oleh solut untuk bermigrasi sepanjang. Waktu retensi standar pestisida aldrin dan dieldrin disajikan pada Tabel I. 
Tabel I. Waktu retensi larutan standar pestisida aldrin dan deldrin

\begin{tabular}{|c|c|}
\hline & Waktu Retensi \\
\hline \multicolumn{2}{|c|}{ Organoklorin } \\
\hline Aldrin & 9,092 \\
\hline Dieldrin & 12,207 \\
\hline
\end{tabular}

Waktu retensi tiap-tiap komponen spesifik, karena ditentukan oleh karakteristik komponen yang bersangkutan, sehingga puncak kromatogram dapat digunakan sebagai parameter kualitatif. Sedangkan untuk keperluan analisis kuantitatif diambil dari fakta bahwa luas puncak kromatogram suatu komponen akan berbanding dengan kadarnya (Willard dkk., 1988).

Dari hasil analisis dengan kromatografi gas menunjukkan bahwa pada sebagian besar sampel tanah dapat terdeteksi yaitu aldrin dan dieldrin, sedangkan pada sampel air hanya sebagian saja yang terdeteksi adanya aldrin dan dieldrin.

Keberadaan aldrin dan dieldrin pada lahan pertanian meliputi tanah dan air dapat disebabkan oleh penggunaan aldrin dan dieldrin sebagai pengendali hama tanaman pertanian di masa lampau atau penggunaan pestisida yang tidak tepat sasaran. Pada sampel air, hanya sedikit sampel yang mengandung residu aldrin dan dieldrin, hal ini terkait dengan solubilitasnya yang rendah dalam air, selain itu senyawa aldrin dan dieldrin terikat oleh partikel tanah, seperti lempung dan materi organik, sehingga potensial senyawa tersebut untuk mengalami leaching adalah rendah. Kisaran residu pestisida aldrin dan dieldrinpada tanah dan air disajikan pada Tabel II.

Aldrin. Aldrin merupakan nama dagang untuk senyawa yang mengandung 95\% HHDN (1,2,3,4,10,10-heksakloro-1,4,4a,5,8,8a-heksahidro-e kso-1,4-endo-5,8-dimetanonaftalen). Aldrin diproduksi dengan reaksi Diels-Alder antara heksaklorosiklopentadiena dengan bisikloheptadiena berlebih pada temperatur $100^{\circ} \mathrm{C}$. Dalam penelitian ini, residu aldrin yang terdeteksi pada tanah, air dan bawang merah berturut-turut adalah 4,8-64,8, tidak terdeteksi-1,0 dan 16,8-127,6 ppb. Residu pestisida aldrin pada tanah dan air di ekosistem sawah irigasi dan sawah tadah hujan terdeteksi berturut-turut pada kisaran 1,0-37,5 dan tidak terdeteksi-4,2 ppb. Residu aldrin tersebut dimungkinkan akibat penggunaan pestisida aldrin di masa lampau dan sifatnya persisten (Ardiwinata dkk., 1999).

Jika aldrin masuk ke dalam tubuh, maka aldrin dimetabolisme menjadi dieldrin yang dapat mengalami bio-akumulasi dalam jaringan lemak. Aldrin mempunyai fitotoksisitas yang rendah, dimana pada tanaman tomat dan kentang aldrin akan berpengaruh pada tanaman tersebut hanya pada laju aplikasi yang sangat tinggi. Aplikasi aldrin sebanyak $16 \mathrm{~kg}$ bahan aktif/ha selama 2-3 minggu pada tanaman tomat, menunjukkan perkembangan akar dan laju pertumbuhan yang terhambat. Waktu paruh aldrin di tanah kira-kira 1-4 tahun. Dengan adanya sifat persistensi dan solubilitas yang tinggi di lemak, maka hal tersebut mendukung dieldrin mengalami bio-konsentrasi dan biomagnifikasi pada organisme baik sebagai aldrin maupun produk konversinya.

Dieldrin. Dieldrin terikat kuat pada partikel tanah oleh karena itu potensi mengalami leaching dan mengkontaminasi air tanah adalah rendah. Dieldrin mempunyai fitotoksisitas rendah, kecuali pada dosis aplikasi yang lebih tinggi dari dosis yang dianjurkan.

Dalam penelitian ini, residu dieldrin terdeteksi pada sampel tanah dan bawang merah masing-masing pada kisaran tidak terdeteksi-6,0 dan 9,2-90,8 ppb, sedang- kan pada sampel air hanya satu sampel saja yang terdeteksi yaitu sebesar 1,2 ppb. Hashimoto (2007) melaporkan konsentrasi dieldrin pada tanah, akar, daun dan buah beberapa sayuran di Tokyo, diantaranya adalah brokoli, dimana konsentrasi dieldrin yang terdeteksi sebesar 30,0-220 ppb (tanah) dan 23-38 ppb (akar), sedangkan pada sampel daun tidak terdeteksi adanya residu dieldrin.

Tabel II. Kisaran residu pestisida aldrin dan dieldrin pada sampel tanah dan air

\begin{tabular}{lcc}
\hline & Senyawa & Kisaran Residu (ppb) \\
\hline & Tanah & Air \\
Aldrin & $(4,8-64,8)$ & $($ tidak terdeteksi-1,0) \\
Dieldrin & $($ tidak terdeteksi-6,0) & $($ tidak terdeteksi-1,2) \\
\hline
\end{tabular}


Adanya sifat persisten, dikombinasikan dengan solubilitas dieldrin yang tinggi dalam lemak, menyebabkan dieldrin dapat mengalami biokonsentrasi dan biomagnifikasi dalam organisme. Dieldrin mempunyai waktu paruh di tanah kira-kira 5 tahun. Dieldrin mempunyai solubilitas dalam air yang rendah, stabilitas yang tinggi dan semi-volatil, menyebabkan dieldrin dapat melalui proses transpor yang panjang.

\section{KESIMPULAN}

Berdasarkan hasil penelitian ditemukan bahwa sampel tanah dan air terdeteksi adanya residu pestisida aldrin dan dieldrin. Kisaran residu pestisida pada sampel tanah untuk aldrin $(4,8-64,8 \mathrm{ppb})$ dan dieldrin (tidak terdeteksi-6,0 ppb), sedangkan pada sampel air untuk aldrin (tidak terdeteksi-1,0 ppb) dan dieldrin (tidak terdeteksi-1,2 ppb). Residu pestisida pada sampel sampel air di lahan pertanian Desa Srigading masih berada di bawah baku mutu air yang telah ditetapkan.

\section{DAFTAR PUSTAKA}

Ardiwinata, A.N., Jatmiko, S.Y., dan Harsanti, E.S., 1999, Monitoring Rresidu Insektisida di Jawa Barat, Risalah Seminar Hasil Penelitian Emisi Gas Rumah Kaca dan Peningkatan Produktivitas Padi di Lahan Sawah, Bogor, 91-105.
Ert, M.V. dan Sullivan, J.B., 1982, Organochlorine Pesticides, dalam Sullivan, J.B. dan Krieger, G.R. (Ed.), Hazardous Materials Toxicology, William and Wilkins, London.

Ishii, Y., 2003, Development of Efficient Methods for Pesticide Residue Analysis of Agro-Environmental Samples, J. Pestic. Sci., 28, 217-218. 218.

Laba, I.W., 2000, Analisis Dampak Penggunaan Insektisida Menuju Pengendalian Hama yang Ramah Lingkungan, Semi Orasi di Balai Penelitian Tanaman Pangan Rempah dan Obat, Bogor, Maret 2000.

Lee, H.B., Chau, A.S.Y., Kawahara, F., 1982, Organochlorine Pesticides, dalam Chau, A.S.Y. dan Afghan, B.K., Analysis of Pesticides in Water, vol. 2, CRC Press, Florida.

Komisi Pestisida, 1997, Metode Pengujian Residu Pestisida dalam Hasil Pertanian, Departemen Pertanian, 377.

Sa id, E.G., 1994, Dampak Negatif Pestisida, Sebuah Catatan bagi Kita Semua, Agrotek, vol. 2 (1), Bogor, 71-72.

Willard, H.H., Merritt, Jr., Dean, J.A., Settle, Jr., F.A., 1988, Instrumental Method of Analysis, edisi 7, Wadsworth Publishing Co., California. 